\title{
On the Polymorphism of the Green Algae and the Principles of their Evolution'.
}

\author{
BY \\ DR. ROBERT CHODAT, \\ Professor of Botany in the University of Geneva.
}

$\mathrm{T}$

HE classification of the Chlorophyceae has from time to time been the subject of numerous discussions, and even now it is by no means considered as settled. After comparing the different systems proposed by Rabenhorst ${ }^{2}, \mathrm{Gay}^{3}, \mathrm{Klebs}^{4}$, De Toni ${ }^{5}$ and others, it is easy to understand how it could be possible for so distinguished a botanist as Sachs ${ }^{6}$ to say : 'It is certainly a great mistake to oppose the Chlorophyceae to the other Algae (Cyanophyceae Rhodophyceae, Phaeophyceae) as a distinct type; such a division has nearly the same value as one in which the Phanerogams destitute of chlorophyll should be opposed to the green Phanerogams and in which both should be considered as distinct types. In the Chlorophyceae of the systematist several archetypes lie hidden, each of which corresponds in its phylogenetic rank to the Archegoniatae, the Florideae, the Phaeophyceae, \&c. It is not possible, howcver, in the present stage of investigation of the

${ }^{1}$ Read before the Botanical Section of the British Association at the Liverpool Meeting, 1896 .

${ }^{2}$ Rabenhorst, Fl. Europ. Algar.

${ }^{3}$ Recherches sur le développement et la classification des Algues vertes, Paris, I 89 I.

* Ueber die Organisation einiger Flagellatengruppen, Untersuch. aus dem Bot. Institut, Tübingen, $\mathrm{I} 88 \mathrm{I}-5$, p. 300 , and Beitr. z. Kenntniss niederer Algenformen, Bot. Zeit. I $88 \mathrm{I}$.

5 Sylloge Algarum.

${ }^{6}$ See Sachs, Phylogenetische Aphorismen, Flora, I896, p. 199.

[Annals of Botany, Vo1. XI. No. XLI. March, I897.] 
Green Algae, to discover the archetypes in the chaos of the Chlorophyceae.'

Sachs ${ }^{1}$ will for the present only recognize as archetypes the Cyanophyceae, Phaeophyceae, Rhodophyceae, Conjugatae (with Bacillariaceae), Siphoneae, and Archegoniatae. He includes the order Coleochacteae in the Archegoniatae, separating it from the Green Algae-an arrangement which I am unable to accept, for reasons presently to be explained.

One cannot too strenuously oppose such a conception of the archetypes. It is very clearly evident that the most striking resemblance exists between the Phaeophyceae and the Chlorophyceae; the production of zoospores the origin and development of sexuality, and the progressive development of the thallus occur in a similar manner in both groups. Their systematic rank as archetypes is of no higher value than that of the Bryophyta compared with the Pteridophyta.

Whilst agreeing with Sachs in regarding the Conjugatae as forming a very distinct order, I cannot go so far as he does when he removes them from the Chlorophyceae and groups them with the Bacillariaceae, a quite distinct and remote order belonging to the Phaeophyceae.

Just as we find in the Archegoniatae several distinct groups, such as the Mosses, Ferns, Equisetaceae and Lycopodineae, which cannot at present be traced back to any known common ancestor, so there are in the Chlorophyceae such orders as Oedogoniaceae, Sphaeropleaceae, Conjugatae, and Siphoneae, which are only separated from the others by certain tendencies already known in the whole group.

The Conjugatae, for example, are chiefly characterized by the mode of their fertilization. Conjugation, however, exists in certain species of Chlamydomonas (C. Braunii) ${ }^{2}$. Very highly differentiated chromatophores are also to be found in the Volvocineae ${ }^{3}$, and the zygotes of these are not very different from

1 Loc. cit., p. $20 \mathrm{I}$.

${ }^{2}$ Gorochankin, Beiträge zur Kenntniss der Morphologie und Systematik der Chlamydomonaden, Bull. Soc. Nat. Moscou, No. 3, I89o.

See the above-quoted paper; also Schmidle, Chlamydomonas Kleinii, Flora, 
those of the Desmidiaceae. Rooting hairs are not only known in the true Chlorophyceae but also in the Conjugatae ${ }^{1}$, and the equality of the cells of the filaments is a very common character in both groups.

With respect to the Siphoneae, which constitute a very special group, I think that the Vaucheriaceae can be detached from them with even more reason than the Conjugatae from the true Chlorophyceae. The multiplicity of the nuclei is not only common to the Siphoneae but also to many Chlorophyceae at an adult stage of their cells (Cladophoraceae, some Pediastreae) ${ }^{2}$.

In this paper I shall set aside those orders which by the fixity of their characters, or their morphological differentiation, constitute very peculiar and definite groups among the Chlorophyceae.

\section{Chlorophyceae}

A. Euchlorophyceae

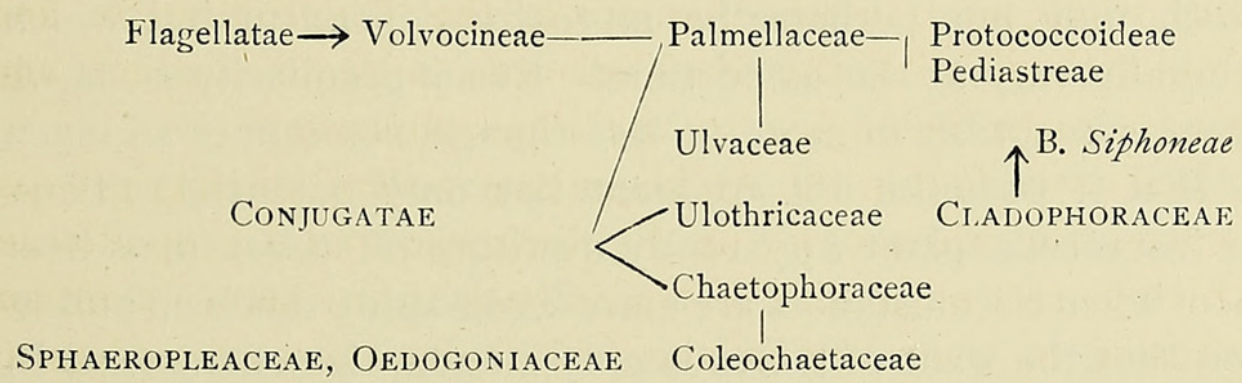

As in similar cases, the proper course to adopt in order to discover affinities is to ascertain the complete development of each type under consideration, and to find out the modifications it undergoes under various circumstances, both in its natural habitat and also under cultivation.

I 894; and Chodat, Histoire des Protococcoidées, Bull. Herb. Boissier, IV, I896, p. 277 .

1 Borge, Ueber die Rhizoidenbildung, Upsala, 1894.

2 Askenasy, Ueber die Entwicklung von Pediastrum, Ber. d. D. Bot. Gesellsch., 1888, Heft 3. And also Chodat et Huber, Recherches expérimentales sur Raphicium, Bull. Soc. Botan. Suisse, 1895, t. v. 


\section{Ioo Chodat.- On the Polymorphism of the Green}

To know some, or even all, of the constant characters only is in no way sufficient ; because if they are absolutely constant, the groups which are endowed with them become very sharply delimited, and their relation with other groups is very obscure, as for instance in the Characeae. It is only when we find representatives in which the important characters are altered or combined with peculiarities recalling other groups that we are able to put forward a theory as to the affinity of the family. The theory will be of no value until the induction drawn from comparative morphology leads us to find in the general life-history of the organism some gradual analogy showing a very definite tendency.

Thus, for instance, in the Archegoniatae the archegonium and antheridium (putting aside the details of their organization) are very constant characters; whereas we see in the reduction of the number of spores, or the progressive reduction of the prothallium, analogies tending to a very definite end.

In natural groups there are sometimes concomitant characters which may not perhaps be mutually dependent but which generally vary at the same time. Every peculiarity is, as we know, susceptible of more or less change, sometimes so much so that it becomes not apparent, but only potential. Thus, for instance, a plant apparently destitute of leaves may bear them when circumstances are more favourable; this is an indication that the want of leaves is only an adaptive character. In some cases the leaves are only found in the younger stages, the plant being afterwards entirely destitute of them. In this case the evolution or life-history of the plant in its totality will be necessary in order to determine its affinities.

For this reason I hoped to derive some fresh information from the variability, or, as it has been often called, the polymorphism, of the lower Chlorophyceae.

The theory ${ }^{1}$ put forward in this paper is the result of a great many observations extending over several years, on

${ }^{1}$ See also Chodat et Huber, Remarques sur le système des Algues vertes inférieures, Archives Sc. Phys. et Nat. Genève, t. 31, p. 395. 


\section{Algae and the Principles of their Evolution. IO I}

material obtained partly in nature and partly by the aid of pure cultures, some of them under the microscope. I have drawn no conclusions from my work which are not basedfirstly, on the fact that on the same plant (filament or colony) forms which had been formerly considered as distinct grow in direct connexion (Cystococcus, Pleurococcus); secondly, on the observation under the microscope of the production of spores and zoospores in plants which up to now were considered destitute of them (zoospores of Eremosphaera, spores of Scenedesmus, larval condition of Chlamydomonas, \&c.); thirdly, on the fact that in a pure culture all the individuals, or nearly all, underwent a transformation which could be easily followed (filament of Pleurococcus, the fixed forms of Raphidium, \&c.); and, fourthly, on the observation that under changed conditions the new forms are always in relation to their surroundings (Palmella, Monostroma, Pediastrum). All these observations have been verified a great many times ${ }^{1}$.

Which are the lowest of the Green Algae it is not easy to say, because the most simple, namely, those from which I am inclined to derive the others, are still very highly organized, and those apparently less complex are merely reduced forms. Hence it would not be possible for a philosopher to take the lower Green Algae as a basis for the theory of the origin of life.

It is permissible, however, according to my observations, to trace the principal groups of the Chlorophyceae back to the little order of the Palmellaceae, in which are comprised the following genera: Palmella (miniata) ${ }^{2}$, Tetraspora, Gloeocystis and Apiocystis.

Palmellaceae. Their gelatinous general envelope is produced by the confluence of the special gelatinous cell-walls. In Palmella the cells are grouped together in all directions of space; whilst in Tetraspora they are regularly disposed

1 These observations are quite independent of the theories of polymorphism which were formerly advanced by Kützing, Hansgirg, and Borzi, and which were not derived from direct observations or pure cultures.

${ }^{2}$ See Chodat, Matériaux pour servir à l'histoire des Protococcoidées, Bull. de l'Herbier Boissier, 1894, t. 2, p. $5^{8} 5$. 


\section{Chodat.- On the Polymorphism of the Green}

in one plane. The cell divides in two distinct ways. In the first, after the first or second segmentation within the gelatinous cell-wall of the mother-cell, the cell-contents are arranged as in Tetraspora. This arrangement I have called tetrasporoid, or, when the dividing new cell-walls are more consistent, pleurococcoid. This has been very often described as vegetative division.

When the cell-wall is more roundish the new cells have a tendency to group themselves in three directions, viz. as if occupying the angles of a tetrahedron: this is the tetrahedric division, commonly manifested in Gloeocystis ${ }^{1}$. This I shall call Gloeocystis-division.

The cells of the Palmellaceae in every stage are, on leaving the envelope, capable of swarming as zoospores. As the cells vary greatly in size there is also great variety in the zoospores.

In certain conditions, as for instance when the solution in which the Algae are cultivated becomes more concentrated, the cell-walls grow more consistent ; the products of division not being able to separate themselves from each other, division goes on, and then this cell is characterized as a sporangium. By the absorption of the separating cell-walls in the interior of the mother-cell, the daughter-cells can assume their rounded form.

Between this formation and the Gloeocystis-stage there is only a difference in the consistency of the wall of the mothercell, and in the degree, more or less, of absorption of the separating walls of the daughter-cells. Very gradual intermediate conditions are also to be found, and are the best demonstration that in such lower forms no true distinction is to be made between the so-called free cell-formation and the vegetative division. This is very clearly shown in the genera Monostroma ${ }^{2}$, Palmella, and especially in Pleurococcus.

From these three principal conditions, which are very equally represented in the true Palmellaceae, we can derive

${ }^{1}$ See Gay, loc. cit., p. $9^{2}$.

${ }^{2}$ See Chodat, Remarques sur le Monostroma bullosum, Bull. Soc. Bot. France, Session Extraordinaire, I 894, t. 4I, p. cxxxiv. 
the three important tendencies which rule over the lower Green Algae.

A. The zoospore-condition, namely, the unicellular motile stage, becomes the leading principle in the Volvocineae, in which the two other conditions are only transient or subordinate.

B. The sporangium-condition, that is to say the unicellular motionless stage with a consistent cell-wall, is in the second group the leading character, the two others being only accidentally realized, or merely transient (Pleurococcoideae).

C. The Tetraspora-stage, namely, where the non-motile cells are connected by regular cell-walls at right angles, or nearly so, arising from the division mentioned above, becomes a preponderant character in the Ulvaceae and the filamentous Algae by the increasing of the consistency of the walls, which is the condition of a more definite form of tissue or filaments; whilst the two others are merely transient of reduced.

These principal lines being established, each of them may follow a very logical evolution and conform to the leading: principle. In their lower types there will be a less strong fixity of the main characters, and a much greater resemblance to the different conditions of the Palmellaceae.

Volvocineae. The general cell-structure of the Volvocineae is the same as in the Palmellaceae, but with variations due to their special evolution and to their mode of life. In some species of Tetraspora, and especially in the curious genus Apiocystis ${ }^{1}$, each cell of the thallus is already provided with two cilia, but these cilia are motionless.

The unicellular Chlamydomonas species, with their gelatinous envelope, are propagated by bipartition or multipartition within the mother-cell-wall; the division is at first longitudinal, but in most cases very soon becomes transverse by the rotation of the separating wall. Very often the four daughter-cells show a tendency to take the form of the

${ }^{1}$ See S. Moore, Apiocystis a Volvocinea, Trans. Linn. Soc., Vol. xxv, I89o, p. 362. Thuret et Bornet, Notes Algologiques. 


\section{IO4 Chodat.- On the Polymorphism of the Green}

mother-cell by the absorption of the dividing walls within the latter, which is then to be compared to a sporangium with 4-8 or more zoospores. These are set at liberty by the rupture of the sporangium-envelope.

In some cases, though rarely, the sporangial division passes into the Gloeocystis-stage or condition by the gelification of the wall of the mother- and daughter-cells (Chl. pulvisculus, Chl. intermedia).

A very interesting condition is that which I have described in the case of Chl. intermedia ${ }^{1}$. We have here a reduction to a Tetraspora-type, in which the cells are grouped in a single plane. By the further division of each of the four cells this stage is able to assume a very singular form, which I have named the larval stage. In this case each segmentation in the four cells is in a direction perpendicular to the division of the next cell. A similar mode of segmentation is well known in certain Volvocineae (Volvox and Eudorina) ${ }^{2}$. I have observed it in all the genera of this family, and also in the lowest forms, such as Chlamydomonas. This condition has been called the Gonium-stage. It is only a modification of the ordinary Tetraspora-division, for it may already be observed in the true Palmellaceae. The only difference is that here the cell-walls separating the products of the division are only subsequently gelified, so that all the cells lie very close to each other, forming a very peculiar plate-like body.

In Chlamydomonas variations are chiefly found in the cellcontents ; the chromatophore may be continuous or perforated, with or without one or several pyrenoids; the latter are also variable in form in the different species. The species of Sphaerella, with their envelope remote from the body, are also closely related to Chlamydomonas; in the earlier stage ${ }^{3}$ they cannot be distinguished from that genus, and the wall is close to the body. For this reason some young stages of

1 Bull. Herb. Boiss., I 894, loc. cit.

2 Goebel, Ueber Eudorina, Grundzuige der Systematik, p. 4I, Fig. I 7.

${ }^{3}$ Cohn, Nova Acta Leopold XXII. Also, Chodat, Neige rouge du Col des Ecandies, Bull. Herb. Boiss., 1896. 


\section{A lgae and the Principles of their Evolution. 105}

Sphaerella have been described by several authors as new species of Chlamydomonas ${ }^{1}$ (Chl. nivalis, Lagh., Chl. sanguinea). In some forms of Chlamydomonas the cell-walls become more and more reduced and are sometimes altogether wanting. From these forms to the metabolic species and genera ${ }^{2}$, such as Chloraster, Pyraminomonas, and Polyblepharis, the passage is easy.

The genus Gonium, which has been separated in nearly all the systems from Chlamydomonas and placed in a different family, is very closely related to the latter. They may be considered as Volvocineae in which the tetrasporoid-stage is undergone in a motile condition. Gonium sociale can be very easily reduced to a unicellular form which can multiply in this stage for a certain time, as is shown by our pure culture experiments. A Gloeocystis-condition is also very easily obtained by gradual concentration of the nutritive solution. G.pectorale, which at its normal stage is a sixteencelled motile colony, has been reduced in our experiments to four-celled colonies, which are very like $G$. sociale. We could only determine by further cultivation to which of the two species such forms belonged. In these young stages of $G$. pectorale each cell of the four-celled colony divides into sixteen, and thus produces successively or simultaneously four new sixteen-celled colonies. This can be very clearly verified in cases where only a single cell of the tetrad divides. This species is also capable of subsisting in a unicellular stage.

In Pandorina the earliest stage is the larval condition, which is transformed by degrees into a globular condition by the rolling in of the edges; in certain cultures of this species, however, I could obtain motile stages of the shape of Gonium pectorale ${ }^{3}$, only less regular; and also by gelification, restingstages like the Gloeocystis-stage of Gonium sociale.

${ }^{1}$ Lagerheim, Die Schneeflora des Pichincha, Berichte der Deutsch. Bot. Ges. I $89^{2}$, p. $5^{\text {I } 7}$, tab. xxviii.

${ }^{2}$ See Dill, Die Chlamydomonas und Verwandte, Jahrbuicher fuir wissensch. Bot. xxviii, 1895 .

3 Loc. cit., Matériaux pour servir, \&c., I, pp. 593 and 597. 


\section{Chodat.- On the Polymorphism of the Green}

The origin of the thirty-two cells of the coenobium of Eudorina is the same as in Pandorina; we have here merely the larval stage more advanced in division, following the same law. By degrees the thirty-two cells thus formed group together into an ellipsoid, which at first is open at one end. $\mathrm{Up}$ to the adult condition this origin is still apparent, the two poles being different. Non-sexual reproduction by the formation of a coenobium of four to eight cells arranged as in Pandorina, viz. close to one another and not surrounding a gelatinous body, is very often produced in our cultivations. These may be easily distinguished from Pandorina by the mode of attachment of the cilia and the more globular shape of the cells.

The origin of a Volvox-colony is quite the same ${ }^{1}$. The larval-condition is here still more pronounced than in the others; but owing to the greater specialization of the individuals composing such a colony, the polymorphism is less marked. A unicellular stage is up to the present unknown. Thus considered, the Volvocineae constitute a very natural group in which the prevailing tendency is to replace the resting-stage of similar Palmellaceae by the motile condition. The evolution of the group can be followed step by step. As has been demonstrated in Chlamydomonas, we can trace two different lines of development; one has a tendency to retain the unicellular condition, the other to form a more or less complicated colony.

The possibility of an indefinite variation in Chlamydomonas is also very clearly shown by the variability of the cellcontents, which are very uniform in the other Volvocineae, and still more in the different forms of sexuality found in this genus. Isogamy, heterogamy, and conjugation ${ }^{2}$ have been observed; whilst from the isogamous Chlamydomonas or isogamous Gonium ${ }^{3}$ to the very highly differentiated anthero-

${ }^{1}$ See Kirchner, Stein und Klein, in Pringsheim's Jahrb. f. Wiss. Bot. XX, and in Cohn's Beitr. zur Biolog. III.

${ }^{2}$ Gorochankin, loc. cit.

${ }^{3}$ Chodat, Matériaux, I, p. 597 . 
zoid and oosphere of Volvox, there are the two graduated intermediate stages in Pandorina and Eudorina.

Protococcaceae.-In the same way that it is possible to derive the Volvocineae theoretically from the Palmellaceae by the prevalence of one of their peculiarities, namely, their motile stage, it is not less natural to imagine a similar origin for the Protococcoideae, in which group the motionless sporangium-stage is the most important.

As the close connexion between the two groups is not so clearly apparent as in the former case, we may consider the Protococcoideae either as the product of a special evolution from a reduced stage of filamentous Algae; or else, as appears to me more natural, as the direct product of the evolution of sporangium-conditions in supposed Palmellaceae.

In the lower forms there are globular cells with smooth or more or less ornamented cell-walls ; the latter are generally the firmest. Their propagation takes place by the development of zoospores or spores. All their reproductive processes, however, show a very marked tendency to transform these motile elements into resting-spores.

We have in Golenkinia radiata (Chod.) ${ }^{1}$ a particularly instructive case. The globular cell has a rather thick cellwall with filiform radiating prolongations; multiplication takes place by discharging four naked and half-amoeboid spores, which soon become clothed; in other cases the cell can be revived by the extrusion of its cell-contents provided with a new smooth though thin cell-wall. Multiplication in this stage takes place by the production of quadriciliate zoospores. I have also described the same in the case of a gelatinous Gloeocystis-condition. The production of motile elements is replaced in the adult stage by naked non-motile spores, which under special conditions may be transformed into very definite spores with thick cell-walls.

Palmellococcus ${ }^{2}$ is a genus producing in its natural habitat

${ }^{1}$ Chodat, Golenkinia radiata, Journ. de Botanique, I894, tab. 8 , p. 305.

2 Chodat, Matériaux, I, p. 600, loc. cit. 


\section{I08 Chodat.- On the Polymorphism of the Green}

(wet walls) from two to four spores with rather thick walls. Simply by cultivation in common water the production of numerous naked spores is obtained in a few hours. They are, as in the former case, extruded by the gelification of the separating walls, and finally this substance disappears by solution. The nature and persistency of this material plays a very important part in the evolution of this group, as will shortly be shown. The limit of the number of normal spores is as a general rule two or four; the maturation of these spores is rapid, and when they are discharged from the mother-cell they have already acquired the peculiarities of the latter. In this case it is not surprising that the production of zoospores takes place so rarely.

The form of the mother-cell is in the lower species, or in the lower conditions, globular, but in some other species or adult conditions it becomes altered, and a great variety is found among the representatives of this group (Oocystis, Kirchneriella ${ }^{1}$, Lagerheimia ${ }^{2}$, Nephrocytium).

These different forms existing, two kinds of reproduction can take place. First, the cell-contents being divided into four (as is the case in most of them), these are sometimes only discharged very tardily. Growth takes place within the mother-cell, and by direct heredity these spores assume by degrees the same form as the mother-cell. The most striking example is given in Lagerheimia genevensis, a single-celled ellipsoid form, with four to eight long prolongations; the spores at the moment of their expulsion, and even before, are provided with the same appendages. Such a spore, having at the moment of its extrusion the form and external peculiarities of the mother-cell, has been named by me an autospore.

In such cases this mode of reproduction, although the commoner and more fixed mode, can be replaced under other conditions by true spores, and also, but very rarely, by zoospores, from which the others are derived, as is in some

1 Chodat, Bull. Herb. Boiss., I895, p. 30I, Fig. 3.

${ }^{2}$ Sur le genre Lagerheimia, Nuova Notarisia, I895, p. 86. 
cases very clearly shown, partly by experiment, partly by comparison with allied species.

Sometimes the autospores are after their extrusion quite free (Lagerheimia, Oocystis p. p., Dactylococcus), sometimes they are surrounded by the gelatinous envelope formed as stated above; this is the case in Kirchneriella, Nephrocytium, \&c. Lastly, the autospores which are not in this case surrounded with this jelly, are united together by threads formed of this substance, as in Dactylococcus infusionum 1 . It will be easily understood that under such conditions the arrangement is very variable, the cells being attached together either in one continuous row or in radiating threads, or forming a branched gelatinous filament.

In this case the form of the mother-cell is susceptible of great variation (in the same species), the more modified form being a spindle-shaped cell. All these forms may be obtained in a pure culture at the same time by gradual transformation. When the four spindle-shaped autospores are not set free by the solution of the gelatinous matter, they often remain attached in a single row as they were in the mother-cell, and by their expansion in a plane constitute the well-known coenobium of Scenedesmus acutus. All these transformations, and those above described, I have observed a great many times, and it is very easy to repeat them.

As a further step, this little coenobium producing similar autospores united together in a row at the instant of their expulsion, the production of an auto-colony takes place. Under commonly observed conditions this so often occurs that it has been considered as the only mode of reproduction in Scenedesmus. It becomes more constant, however, in some other species of the same genus, such as $S$. quadricanda, which is generally provided with long spines. In Raphidium ${ }^{2}$ we have in a way a repetition of this method of propagation; the long spindle-shaped cell divides within the thin mother-

1 Chodat et Malinesco, Sur le polymorphisme du Scenedesmus acutus, Bull. Herb. Boiss., I896, t. iv, p. I84; et ibid, I893, p. 640; et Chodat, Matériaux, I, pp.602,608.

${ }^{-2}$ Chodat, Matériaux, I, p. 608, tab. 26. 


\section{IO Chodat.- On the Polymorphism of the Green}

cell twice transversely; the four superposed cells show a tendency to elongate and to assume the spindle form of the mother-cell. Finally, by absorption of the cell-wall they are set free, as though they had originated by simple fission.

When there are some filaments of Vaucherix or other Algae in a culture of Raphidium Braunii, the latter plants develop a little disk at one end by which they become attached to the filament. In this case the difference between the two poles is clearly demonstrated by the behaviour of the products of division. In most of the individuals so attached, the wall of the mother-cell becomes more resistent at the base, and only the upper part is dissolved; the new Raphidia are discharged and very often remain attached to the edge of the cupule-like mother-cell. This process being repeated, a very elegant bush-like colony arises, and a certain similarity to the case of Sciadium is produced.

The polymorphism of this species is very considerable. A similar evolution of the fixed stage of Dictyosphaerium has also been described after repeated observations.

All these different Protococcoideae can be reduced to unicellular globular conditions, in which they behave like the sporangia of Palmella or Dactylococcus ${ }^{1}$. I have also obtained from all the genera a gelatinous condition like Palmella by the suppression of the motile element and the disappearance of sexual differentiation. Up to the present time isogamy has been described in only a very small number of species.

The Pediastreae constitute only a parallel group or suborder to the former one.

As I have just shown that the coenobium of Scenedesmus, Raphidium and others can be derived from unicellular and spore-producing types, the same theory is also applicable to the Coenobieae. Leaving aside Hydrodictyon, which seems to be a very peculiar type, the others are grouped in several small series.

The first series has as its higher type the curious genus

1 Chodat, Bull. Herb. Boiss., 1895. 
Hariotina, and as intermediate forms the different species of Coelastrum.

It may be imagined that Coelastrum sphaericum, for example, has been derived from a lower form of the Protococcoideae with autospores. As in the former series, the spores may be at the time of their expulsion either free or united together by intermediate mucilaginous matter. In such a theoretical type the autospores would have been grouped in a globular colony. This may often be observed in some very doubtful species, such as the so-called Chlorococcum infusionum, Pleurococcus angulosus, \&c., described by Artari ${ }^{1}$.

One of the causes of the production of auto-colonies, in this and in other cases, is the rapid multiplication of the nuclei. At a very early stage of their development after their extrusion, the cells of the Pediastreae contain several nuclei (4-32-64). By direct heredity each of the cells assumes within the mother-cell the shape of the parent, and when the mother-cell is provided with sculptures or prolongations, as is the case in some species of Coelastrum and in Hariotina, these appendages are already formed at the instant of the extrusion of the new colony.

This theory of the evolution of the group may be demonstrated by the very specific variations of the different species of Coclastrum, for example C. sphaericum ${ }^{2}$. In the ordinary condition the cells of the coenobium of this species remain united together at the time of the birth of the young colonies. The cells of the parent colony are for the most part emptied of their contents; in other cases each of the cells of the coenobium is separated, and can produce a new colony in this condition of desaggregation, or else may give birth to a twocelled body (as occurs in Sorastrum) in the cells of which new colonies are formed. Lastly, gelatinous unicellular or multicellular conditions are possible.

1 Untersuchungen über Entwicklung und Systematik einiger Protococcoideen, Bulletin de la Société Imp. des Naturalistes de Moscou, No. 2, I892, p. 29.

${ }^{2}$ Chodat, Sur l'Évolution de Coelastrum, Bull. Herb. Boissier, ı 896, p. 273. 


\section{2 Chodat.- On the Polymorphism of the Green}

In a similar manner Sorastrum ${ }^{1}$ may be derived from some unicellular Polyedrium, as I have shown; and the same thing is highly probable with respect to Pediastrum, which is connected with the unicellular Polyedrium-forms through the interesting genus Euastropsis ${ }^{2}$. But in this latter small group curiously enough the zoospores are still present ; discharged as in other cases by the walls becoming gelatinous, they remain enclosed in the vesicle, and their evolution takes place within it. Finally, a new coenobium is formed. I have demonstrated by experiment that it is possible to induce Pediastrum to form the new coenobium directly within the mother-cell without the intermediate stage of the enclosed motile cells. By concentrating the nutritive solution, Pediastrum produces new colonies in the manner shown in Coelastrum, i. e. typical auto-colonies.

In Hydrodictyon, which seems to be a very special type, an intermediate condition between Pediastrum and Coelastrum occurs. The swarming stage is attained not, as in Pediastrum, outside the mother-cell, but within it. The question whether Hydrodictyon properly belongs to this group seems to me an open one. Perhaps the likeness to the Pediastreae is due to a convergence rather than to a common origin. There are in fact so many analogies between Cladophora and this genus in the mode of formation of the zoospores, and the constitution of the cell, that a new line of comparison is required.

To sum up: we have in the Pediastreae a repetition of the evolution of the other Protococcoideae, and a great analogy with the Volvocineae in the complication of the thallus, though for reasons which are quite independent in both groups.

Ulvaceae-Chaetophoraceae. The type which is realized in the Ulvaceae is still essentially similar to that of the true Palmellaceae. In fact there is only the greater consistency of the walls and, consequently, the more definite form of the thallus. It is true that here the cells of the thallus are more

\footnotetext{
1 See De La Rue, Sur le développement du Sorastrum, Ann. Sc. Nat., sér. V. น. I7, I873, and Chodat, Évolution des Coelastrum, loc. cit., p. 275.

${ }^{2}$ See Lagerheim, Ueber Arktische Kryptogamen, I, Tromsö-Museum, I 894.
} 


\section{A lgae and the Principles of their Evolution.}

regularly disposed, and the number of the cell-rows also is determinate. With the gradual evolution in the external morphology, the thallus of the marine species becomes very definite, and in some cases, like Enteromorpha, active apical cells play a predominant part in the development of the new tissues. Through the genus Monostroma ${ }^{1}$, and especially through the fresh-water species, the Ulvaceae are closely connected with Tetraspora. The disposition of the cells dividing at right angles, above described in the Volvocineae and Palmellaceae, is here also of very common occurrence. With regard to the early development, there are several very variable modes. The young thallus may take a globular, tetrasporoid, or shortly filamentous shape. The Palmellacondition is also found under certain circumstances in Monostroma, and resting cells with thick cell-walls are very easily formed, as in the Palmellaceae. The production of macroand micro-gametes or zoospores takes place in the same manner, and isogamy is quite as frequently observed. There can be no doubt, therefore, about the close affinity of the Ulvaceae to the Palmellaceae.

The same may be said of the Chaetophoraceae, which constitute another group. The polymorphism of Stigeoclonium is well known ${ }^{3}$; this Alga with its branched filaments can assume a Palmella-condition ${ }^{4}$, and in every stage of its life exhibits some very striking modifications. The adult plant consists of a rhizome with branched filaments and swollen cells, from which rhizome arise further branched filaments terminating in hairs. But the ramifications are very inconstant, and consequently the different species have not been distinguished with accuracy. Each of the cells can separate ${ }^{5}$ from the

1 Chodat, Monostroma bullosum, Soc. Bot. France, loc. cit.

2 Reinke, Ueber Monostroma bullosum, \&c. Jahrb. f. Wissensch. Bot. II, p. $33 \mathrm{I}, \mathrm{I} 878$.

3 Famintzin, Die anorganischen Salze, Bull. de l'Acad. Imp. des Sc. St. Pétersb., XVII, p. 3I.

4 Cienkowski, Zur Morphologie der Ulothrichien, Bull. de l'Acad. Imp. des Sc. St. Pétersb., XXI, I 876 .

5 Chodat et Huber, Remarques sur le système des Algues Vertes, Archives des Sc. Phys. et Nat., Genève, I894, p. 395. 


\section{I1 4 Chodat.- On the Polymorphism of the Green}

whole by forming a macro-zoospore (as in Palmellaceae) or by transformation into a Palmella-stage. The first modification takes place generally in the erect filaments, the second is more commonly found when the plant is in the rhizome stage. Each of these cells can form a globular sporangium with 4-8 quadriciliate zoospores; in other cases subdivisions are effected, as in Tetraspora, and these can gradually pass into a Gloeocystis-condition or Protococcus-condition for the same reasons as above indicated in the Palmellaceae. In the Protococcus-stage (sporangium-condition) the zoospores can be transformed into spores which by mutual pressure become more or less polyhedric. After the destruction of the cellwall these daughter-cells may remain united together and constitute multicellular bodies, from which zoospores or spores similar to those of the mother-cell escape.

But I have also observed the same thing in the erect filaments and also in the gelatinous condition. In all the lower Chaetophoraceae, Ctenocladus, Chactonema ${ }^{1}$, Endoclonium, similar conditions also exist. In the genera Chaetophora and Draparnaldia this is less marked and confined to special developments.

This polymorphism, which shows us so clearly the relation of this group to the Palmellaceae, is of the greatest interest, and is similar to, though not identical with, the following, studied by me in Pleurococcus vulgaris.

This plant is apparently well known. It grows on the bark of trees, on wet stones, on turf in mountainous places or on bare wood in damp places, and is of a characteristic green colour. In opposition to Gay, Artari, and Klebs, who believe in the fixity of the form of this Alga, I have arrived at the conclusion, after three years of continuous research, that its variability under different circumstances is very great. Under this name we must include not only the common form without a pyrenoid, but also the similar one with a pyrenoid $(P l$.

${ }^{1}$ Huber, Sur un état particulier de Chaetonema, Bull. Herb. Boiss., I894, p. 164 . 
simplex, Artari $\left.{ }^{1}\right)$, as well as such very different forms as Cystococcus and Protococcus vulgaris.

This plant having been considered as the type of the sonamed 'Pleurococcaceae' by recent authors, such as Klebs, Wille, \&c., it is necessary to give somewhat full details concerning it.

As generally described in its natural and commonest condition, the four cells are arranged in one plane, and each cell is characterized by a parietal chromatophore. By repeated divisions very regular thalli are formed, in which the cells lie close together. This very common condition of Pleurococcus vulgaris is the aerophilous form, which produces a more or less thick stratum on the bark of trees. In a nutritive solution the culture of this plant, gathered in very dry places, is often impossible. When, however, in such a solution, the aeration is good, some, or all, of the individuals grow very well, and after some days or weeks the formation of a short filament begins by the protrusion of a prolongation continuous with the Pleurococcus-cell. In some cases, out of the four or eight cells of a thallus, only a single one produces such an expansion, so that it is unquestionable that the filament belongs to a true Pleurococcus vulgaris. In other instances from two to eight do the same. The growth of the filaments is always slow, and when they become more elongated division by segmentation occurs. This may also be observed in larger thalli which are covered with short or long hairs arising from nearly all the outer cells. When circumstances are favourable almost all the individuals develop in the same way, and a great many little branched or unbranched filaments spread in every direction. I have not been able to obtain filaments exceeding twelve cells in length; the thalli often appear to be more branched, but this is due merely to the fact that the four initial cells of the normal Pleurococcus from which the filaments originated still remain united; in this case the ramification is radiating. I have repeated these cultures a great number of times, and have always obtained the same result. 
It is not necessary, however, to have recourse to cultures in nutritive solutions; in wet years all these developments can be observed on the bark of shady trees exposed to rain and moisture. I have renewed these experiments by starting with Pleurococcus gathered in various localities in Switzerland and France, and have always arrived at the same result.

A second variation, which is quite as frequent, is the production of spores. In cultures or in fresh conditions this takes place sometimes by the gradual solution of the separating cell-walls of the thallus. During this process the cell-contents acquire a special envelope and become more and more globular. The general envelope of the thallus is not altered, but assumes the function of a sporangium-wall. In this case it may be that on a large thallus one half of the cells undergo this transformation, whilst the remainder retain their normal structure. Some of the cells of these small typical thalli may grow larger and become more globular; at length the latter are separated from the normal cells and constitute very different bodies, in which division of the contents generally takes place very soon, and spores are formed in this way. This production of sporangia is of frequent occurrence in connexion with the normal Pleurococcus cluster of cells, in which I have often observed not only the above-described sporangia but also at the same time more or less developed filaments. This shows very obviously how difficult it is, with regard to this and other productions, to discover the true cause of their formation, when they grow not only under the same conditions but even on the same plant.

Finally, each cell of the more or less complicated cluster of Pleurococcus can be renovated by a similar process as I have just described above for the formation of spores from the vegetative thallus; but in this case the renewed cells retain the same elongated or more or less quadrangular form, and are consequently very like some Stichococcus. But this is only an external resemblance. Stichococcus is quite a different plant, belonging to the Ulothricaceae. All these sporangium- 
formations I have obtained in my pure cultures, and have also observed them in their natural habitats on many occasions.

Naegeli has distinguished under the name of Cystococcus a unicellular Alga which he believed quite different from Pleurococcus. In his drawings the cells are globular, with a stellate chromatophore, and a very distinct pyrenoid, which has often been taken for the nucleus. On one side there is a clear space containing a nucleus. He also describes a cell-division in which the numerous daughter-cells are polyhedric by mutual pressure. It is well known that $C y$ stococcus can produce biciliate zoospores. I have also observed very minute gametes fusing together a short time after their expulsion. This plant, if only known in this stage, could be taken as a type of the Protococcoideae, for in it may be very easily observed the transformation of the zoospores into nonmotile spores. But Cystococcus is not a member of the Protococcoideae at all; it is merely a stage of the development of Pleurococcus.

I have already stated how in the same Pleurococcus the different cells can produce a globular sporangium with spores, a transformation of a part of the thallus into a false sporangium, and branched or unbranched filaments, and the same phases may be observed in the Cystococcus in its typical form, and the true Pleurococcus, which is provided with very different chromatophores. For instance, I have repeatedly noticed on the same thallus, with or without pyrenoids or filaments, typical Pleurococcus-cells with parietal chromatophores, and one or more Cystococcus-cells with a more or less stellate chromatophore. In such cases I have seen the expulsion of the zoospores or gametes, whilst in other cells of the same thallus spores were formed ${ }^{\mathbf{l}}$.

1 There are certainly two varieties or species known under the name of Pleurococcus vulgaris; the first with more or less stellate chromatophores and pyrenoids, which in its Cystococcus-stage can produce motile spores (Pleurococcus vulgaris, Menegh. p. p., non Naeg.), and the other without pyrenoids and with less stellate chromatophores, from which I could not obtain motile elements (Pl. vulgaris, Naeg. p. p., non Menegh.). In my cultures the two remained quite distinct. 


\section{8 Chodat.- On the Polymorphism of the Green}

The appearance of the chromatophore when the Cystococcus form is developed, or in a free condition, is, as usually described, somewhat stellate and always with an incision on one side. By division this appearance often changes into that of a flat cup, the upturned edges of which cause the cells to look as if there were parietal chromatophores.

I cannot sufficiently insist upon the fact that all these various formations are not only found separate and combined on the same spot of bark, but even on the same thallus.

Besides the formations here mentioned, the student can follow step by step in older and more concentrated cultures the development of very curious gelatinous conditions which are very similar to the genus Hormotila described by Borzi.

To sum up: Pleurococcus, in the various conditions of its evolution, may develop branched filaments, sporangia with zoospores, gametes, and spores. This is sufficient ground for removing this plant from the order Protococcoideae, and considering it as a type of the Chaetophoraceae, reduced owing to its existence as a lichen-gonidium.

In this order isogamy only has been described. In a recent paper one of my assistants, Dr, J. Huber ${ }^{1}$, has carefully studied the curious heterogamy of Aphanochaete, of which I had at the critical moment collected specimens growing on Oedogonium. In this epiphyte the central cells of the bilateral thallus become greatly developed and produce oogonia. At this time the latter, like the other cells, are provided with a typical hair. The cells of the periphery contain the antheridia, which are much smaller and paler, sometimes colourless, and grouped in a very similar manner to the antheridia of Coleochaete. The oosphere, which is five to six times larger, is set free by the swelling of the inner side of the cell-wall and the rupture of the upper part of the oogonium. The expulsion takes place suddenly, and the large quadriciliate gametes remain enclosed in the mucilaginous hyaline vesicle, as is the case with the zoospores of the same

${ }^{1}$ Huber, Sur l'Aphanochaete repens, Soc. Bot. de France, Sess. extraordinaire en Suisse, I894. 
plant, which likewise bear four cilia and are smaller. The male gametes are formed in the same way, rarely two in one cell, but the gelified vesicle is rapidly dissolved and fecundation can be effected. The fusion of the male gamete with the very sluggish oosphere, which is at this moment always in front of the empty oogonium, has been observed. It may be compared with the corresponding process in Coleochaete; in the two genera the oogonium and zoospores are homologous. The oosphere and antherozoid have the same shape and the same number of cilia as the zoospores. In Coleochaete pulvinata $^{1}$, for example, the oogonia and the cells which give birth to the zoospores are terminal cells. The antheridia in both genera are also of the same morphological rank; each antherozoid can be compared to a micro-zoospore. To this it may be added that the cells of Coleochaete are provided with chromatophores of the same shape, containing the same pyrenoids; and the hairs and zoospores are so clearly allied to those of the Chaetophoraceae and other Green Algae that we may justly feel greatly surprised to read in a serious paper that the Coleochaeteae ${ }^{2}$ ought to be united with the Archegoniatae, and separated from the Chlorophyceae. It is true the author admits that there is no direct passage from the Coleochaetae to the Mosses and Ferns. On the other hand, this direct relationship does actually exist between this group and the other Chaetophoraceae. Aphanochaete is beyond all doubt the connecting link which unites the two nearly allied groups ; in fact, the only difference between the two consists in the fact that in Coleochaete the oosphere is not motile, and remains enclosed in a sort of archegonium. But it must be remembered that in the other genus the oosphere is almost motionless and remains in front of the oogonium.

If, as we are permitted to believe on comparison with similar cases, the oosphere is merely a macro-gamete which remains enclosed in the cell-wall, the stage of Aphanochaete is of the greatest interest, being the intermediate step between

\footnotetext{
${ }_{1}$ Pringsheim, Jahrb. für wiss. Bot., Band II.

${ }^{2}$ Sachs, loc. cit., pp. I 84,185 , \&c.
} 


\section{20 Chodat. - On the Polymorphism of the Green}

two motile hetero-gametes and the true sexuality realized in the higher types. The form of the oogonium of Coleochaete is simply a fortuitous resemblance to the archegonium, and is not sufficient to establish any homology.

The analogy with Oedogonium, in which the two gametes may be compared to two differentiated zoospores, is much more marked. The number of antherozoids arising from one cell is also comparable, and their origin is quite different from that of the antherozoids of Mosses and Ferns.

All this very clearly indicates a direct affinity between the Coleochaeteae and the Green Algae, which considered as a whole group (the Siphoneae put aside) is quite as natural a one as the Archegoniatae.

With regard to the so-called sporogonium of Coleochaete, there is no dispute about the statement that the ovum undergoes division after fertilization; but this segmentation, which reminds one to a certain degree of the production of the sporogonium in some lower Liverworts, shows a far greater resemblance to similar products in the Green Algae.

The fertilized zygote of Hydrodictyon divides during germination into several zoospores; the same thing is known to occur in Oedogonium. In some Volvocineae, such as Gonium, according to my observations, the zygote gives birth to four zoospores with gelatinous envelopes, whilst in others the zoospores are extruded before division.

From the fact that in the case of Coleochaete the ovum is more protected by the formation of a resistent envelope, germination becomes slower; and as I have already shown that the transformation of zoospores into spores and finally into autospores may be effected, it is evident that a similar adaptation takes place here.

The little thallus of Coleochaete cannot be contrasted with the antecedent plant as an entirely new formation; according to all analogies with other Algae, it constitutes simply the beginning of a normal plant, only modified under peculiar circumstances. Similar small thalli are moreover formed in Aphanochaete, but from zoospores. This is merely the result 
of normal activity due to fertilization, or the increase of nourishment.

Furthermore, we must admit that in the Green Algae antithetic alternating generations cannot be distinguished; for the production of zoospores, spores, and gametes depends on certain circumstances, and occurs in most cases at every stage of the life-history.

In conclusion I may say that all the facts above mentioned relating to the variability of the Green Algae help us in studying the difficult problem of the phylogeny of these plants. It seems to me that it is now easy to understand what are the leading principles in the evolution of the Volvocineae, Protococcoideae, and Ulvaceae. On the other hand, we can now go back step by step from the higher branch of the filamentous Algae, the Coleochaeteae, to the lower Chaetophoraceae, of which Pleurococcus is a genus in a stage of degradation. I could have shown in what manner the Ulothrichaceae are related to the Ulvaceae, by such a series of steps as Ulothrix, Hormidium, Schizogonium, and Prasiola. The Chaetopeltideae are likewise very closely related to the Ulvaceae, and especially to Monostroma. I hope shortly to complete in another paper this theory of the evolution of the Green Algae.

The true affinities of the Green Algae are not by any means so obscure as has been recently asserted by some of the most competent botanists; on the contrary, their phylogeny is especially clear; and the present paper may throw some light on this difficult subject. 


\section{$2 \mathrm{BHL}$ Biodiversity Heritage Library}

Chodat, R. 1897. "On the polymorphism of the green algae and the principles of their evolution." Annals of botany 11, 97-121.

https://doi.org/10.1093/oxfordjournals.aob.a088647.

View This Item Online: https://www.biodiversitylibrary.org/item/233542

DOI: https://doi.org/10.1093/oxfordjournals.aob.a088647

Permalink: https://www.biodiversitylibrary.org/partpdf/318455

\section{Holding Institution}

Smithsonian Libraries

\section{Sponsored by}

Biodiversity Heritage Library

\section{Copyright \& Reuse}

Copyright Status: Not in copyright. The BHL knows of no copyright restrictions on this item.

This document was created from content at the Biodiversity Heritage Library, the world's largest open access digital library for biodiversity literature and archives. Visit BHL at https://www.biodiversitylibrary.org. 